\title{
The Middle/Late Eocene transition in the Eastern Carpathians (Romania) based on foraminifera and calcareous nannofossil assemblages
}

\author{
Raluca BINDIU ${ }^{1, *}$, Sorin FILIPESCU ${ }^{1}$, Ramona BĂLC ${ }^{2}$, Lavinia COCIŞ ${ }^{2}$ and Delia GLIGOR ${ }^{2}$ \\ 1 Babeş-Bolyai University, Faculty of Biology and Geology, Department of Geology, 1 Mihail Kogălniceanu Street, 400084 \\ Cluj-Napoca, Romania \\ 2 Babeş-Bolyai University, Faculty of Environmental Science and Engineering, 30 Fântânele Street, 400294 Cluj-Napoca, \\ Romania
}

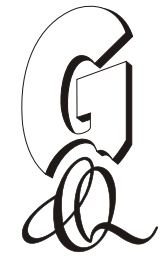

Bindiu, R., Filipescu, S., Bălc, R., Cociș, L., Gligor, D., 2016. The Middle/Late Eocene transition in the Eastern Carpathians (Romania) based on foraminifera and calcareous nannofossil assemblages. Geological Quarterly, 60 (1): 38-55, doi: $10.7306 / \mathrm{gq} .1237$

\begin{abstract}
Foraminiferal and calcareous nannofossil assemblages from the Eastern Carpathians (northern part of the Tarcău Nappe, Romania) were documented and correlated in order to reconstruct the palaeonvironmental settings and provide a biostratigraphic framework of the Plopu Formation. The benthic foraminiferal assemblages are dominated by flysch-type agglutinated taxa, suggesting a bathyal palaeodepth with frequent oscillations of the carbon compensation depth. The agglutinated foraminifera morphogroup analyses suggest different levels of organic matter influx and oxygenation. Both the foraminifera and calcareous nannofossil assemblages suggest a shift between the warm Middle Eocene to the cooler Late Eocene climate. Biostratigraphic data based on calcareous nannofossils (NP15-NP19/NNTe8-NNTe12 biozones) helped to establish the age of the formation. Four assemblages of benthic agglutinated foraminifera (Psammosiphonella cylindrica-Nothia excelsa; Paratrochamminoides spp.-Trochamminoides spp.; Karrerulina spp.-Reticulophragmium amplectens; Spiroplectammina spectabilis) correlated with calcareous nannofossil bioevents supported the placement of the Middle to Late Eocene transition within the Plopu Formation.
\end{abstract}

Key words: microfossils, biostratigraphy, palaeoecology, turbidites, Tarcău Nappe.

\section{INTRODUCTION}

A detailed micropalaeontological study was carried out in the Eocene deep-water deposits of the northern part of the Eastern Carpathians (Plopu Formation, Tarcău Nappe) in order to provide an accurate biostratigraphic framework and palaeoenvironmental reconstructions. Although a significant amount of information on the lithostratigraphy and tectonic settings of the Tarcău Nappe in the Suceava River valley is already available (Joja, 1952, 1955; Joja et al., 1963, 1967; Joja and Manoliu, 1978; Juravle, 2007; Juravle et al., 2008; Bindiu and Filipescu, 2011; Bindiu et al., 2013), the biostratigraphical data are very scarce. This has resulted in prolonged dispute regarding the age of the Plopu Formation due to the fact that the flysch deposits are strongly affected by tectonics, and the biostratigraphical analyses were not consistent throughout all of the lithostratigraphic units.

The continuity and extensive development of the deposits from the Suceava River valley section allowed the documenting

* Corresponding author, e-mail: raluca.bindiu@ubbcluj.ro Received: March 23, 2015; accepted: June 3, 2015; first published online: June 29, 2015 of the biostratigraphy of the Middle to Late Eocene interval and the succession of changes in the benthic foraminifera and calcareous nannofossil assemblages as a result of environmental changes in the basin.

\section{LOCATION AND GEOLOGICAL SETTING}

The area investigated is located in the Suceava River valley, near the village of Brodina ( $47.89052^{\circ}, \mathrm{E} 25.43590^{\circ}$ ). Geologically, it belongs to the northern part of the Outer Moldavides (Săndulescu, 1984) of the Eastern Carpathian flysch, more precisely to the Eocene part of its most important unit, which is the Tarcău Nappe (Joja, 1955; Fig. 1). The geotectonic evolution of the area during the Eocene (Pandele and Stănescu, 2001; Bădescu, 2005; Juravle, 2007) accelerated the dynamics of the basin, leading to more prominent environmental changes when compared to the Paleocene. In the proximal areas related to the Carpathian source, sandy formations are present; while the distal areas are characterized by alternations of sandy and silty/muddy deposits with a calcareous character (Juravle et al., 2008). This resulted in the occurrence of three different lithofacies with different lithologies and palaeontological content (lonesi, 1971; Gigliuto et al., 2004; Juravle et al., 2008), on going from west to east (Fig. 2): Tarcău, Tazlău, and Doamna. The Tarcău lithofacies is defined by the 


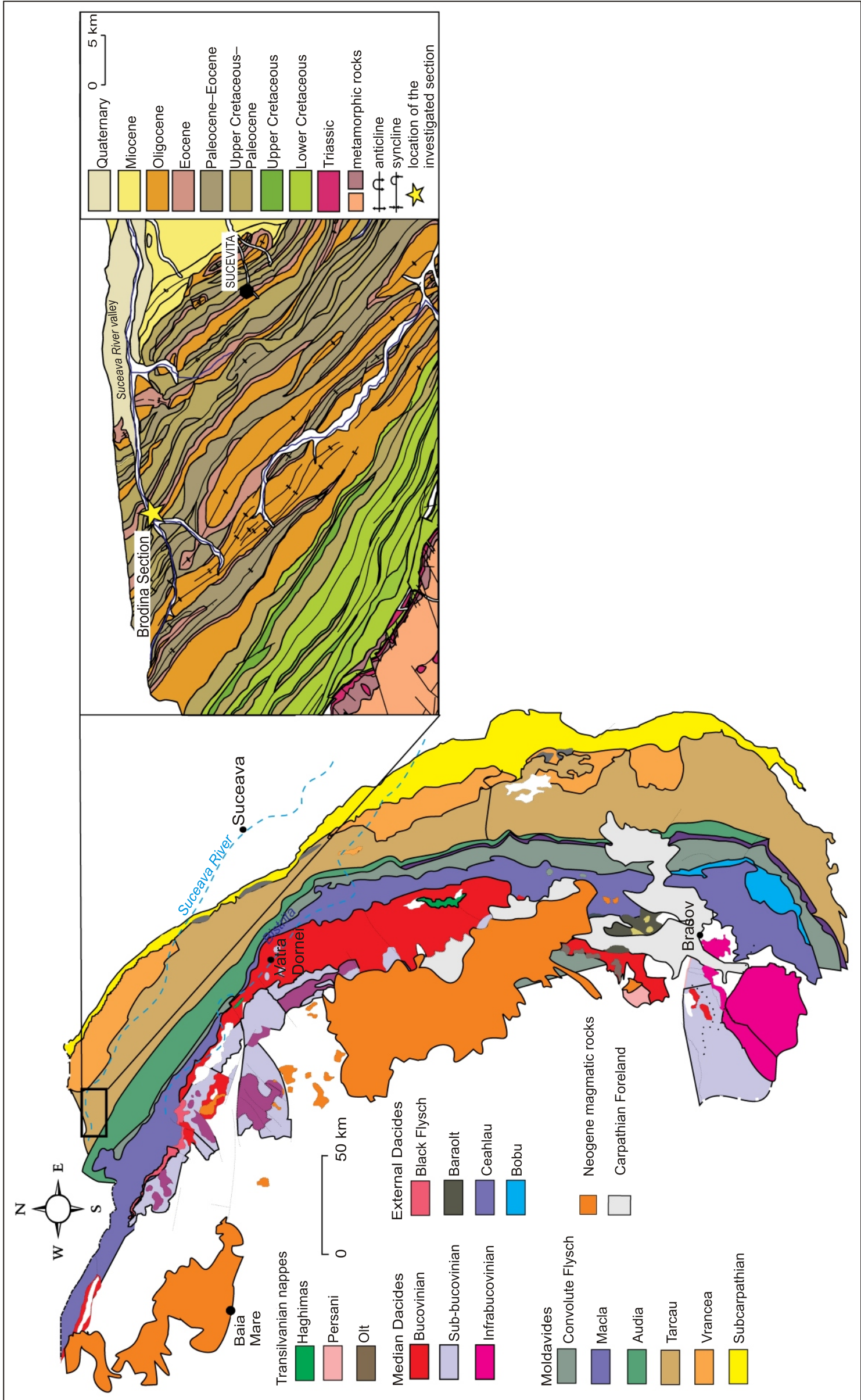

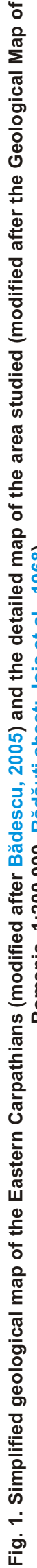




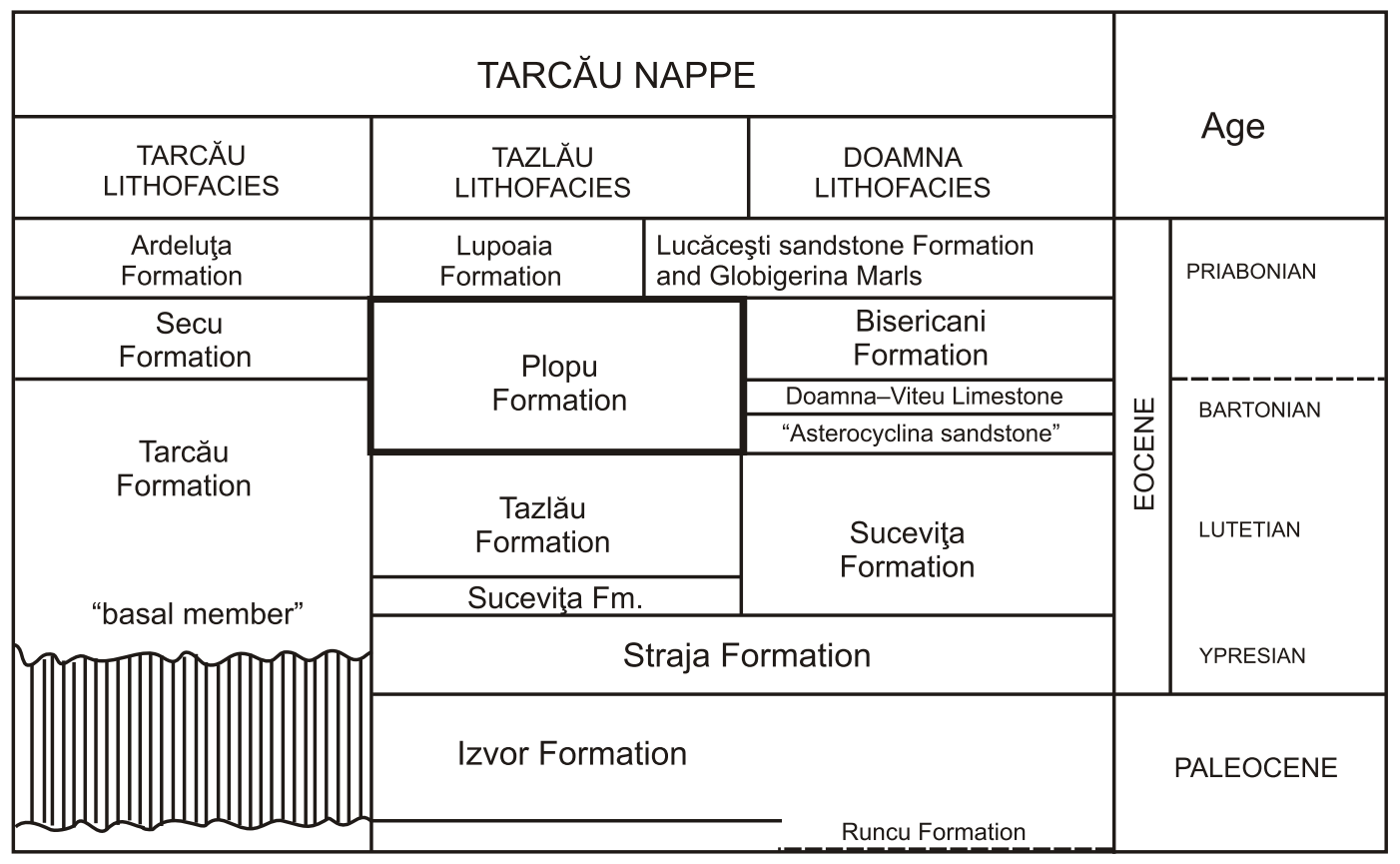

Fig. 2. Paleogene lithostratigraphic scheme of the Tarcău Nappe (modified after lonesi, 1971)

predominance of a sandy flysch where the percentage of sandstone present in the lithological column exceeds $80 \%$ (Mutihac and Ionesi, 1974; Grasu et al., 1988); the Doamna lithofacies is characterized by the presence of sandy-calcareous-clay flysch in the lower part (Joja, 1960), and in the upper part the Doamna limestone is present (Athanasiu et al., 1927; Mutihac and Ionesi, 1974); the Tazlău lithofacies has a mixed character of both the Tarcău and Doamna lithofacies (Ionesi, 1971; Mutihac and Ionesi, 1974). In the area studied, the Plopu Formation belongs to the Tazlău lithofacies and is represented by turbidites with a rhythmical alternation of green and grey calcareous clays with thin sandstones, and by three intervals of red clays in the lower part of the section (lonesi, 1971; Mutihac and lonesi, 1974; Juravle, 2007; Juravle et al., 2008).

\section{MATERIAL AND METHODS}

Thirty-six samples were collected from a continuous succession of the Plopu Formation in the Suceava River valley, the Brodina section (Fig. 3), in order to investigate the foraminifera and calcareous nannofossil assemblages. The samples were split into two sub-samples; the first set of samples was used to study foraminiferal assemblages, while the second was analysed in order to capture the changes in calcareous nannofossil assemblages.

The samples for foraminifera were prepared using the standard micropalaeontological method; they were dried, weighed, and disintegrated in a solution of sodium carbonate. Then the material was washed on a $63 \mu \mathrm{m}$-mesh sieve (Armstrong and Brasier, 2005). Wherever possible, 300 foraminiferal tests were picked and identified under a stereomicroscope. Several specimens were examined in detail using a JSM-JEOL $5510 \mathrm{LV}$ scanning electron microscope. Abundant data were processed at the species level. Specimens of tubular taxa (Rhizammina,
Bathysiphon, Rhabdammina, Nothia), usually recovered only as fragments, were counted just for consistency. Palaeoecological methods include the agglutinated foraminifera morphogroups (Nagy et al., 1995; Van der Akker et al., 2000; Kaminski and Gradstein, 2005; Cetean et al., 2011; Murray et al., 2011; Setoyama et al., 2011, 2013) and the diversity of foraminiferal assemblages (Hulbert, 1971). The morphogroup analysis is based on the concept of foraminifera morphology and the idea that individuals with different test shapes have different habitats and different feeding strategies, therefore the changes in the relative abundance of morphogroups in the assemblages can reflect environmental changes (Corliss, 1985; Jones and Charnock, 1985; Murray et al., 2011). The samples for calcareous nannofossils were processed using the gravity settling technique (Bown and Young, 1998). The calcareous nannofossils study was performed using a light microscope at $1000 x$ magnification and the photographs were captured with a AxioCam ERc5s digital microscopy camera. At least 300 specimens were counted for the quantitative study. Another 1000 FOV (fields of view) were examined to identify rare taxa. The individual abundance of the taxa observed was assessed as follows: VR - very rare: 1 specimen to more than $50 \mathrm{FOV}$; R rare: 1 specimen to $21-50$ FOV; $F$ - few: 1 specimen to $11-20$ FOV; C - common: 1 specimen to 2-10 FOV; A - abundant: more than 1 specimen per FOV.

Some reworked specimens (Cretaceous) were identified in the samples studied. This is due to erosion processes during tectonic instability. The Late Eocene interval is characterized by an increasing number of specimens of reworked species.

The biozones were defined using the biozonation schemes of Martini (1971) and Varol (1998) for calcareous nannofossils, and of Bratu (1975), Geroch and Nowak (1984), Berggren et al. (1995), Kaminski (2005) and Kaminski et al. (1989) for foraminifera. The agglutinated foraminifera taxa identified are listed in Appendix $1^{*}$, while the calcareous nannofossils are 


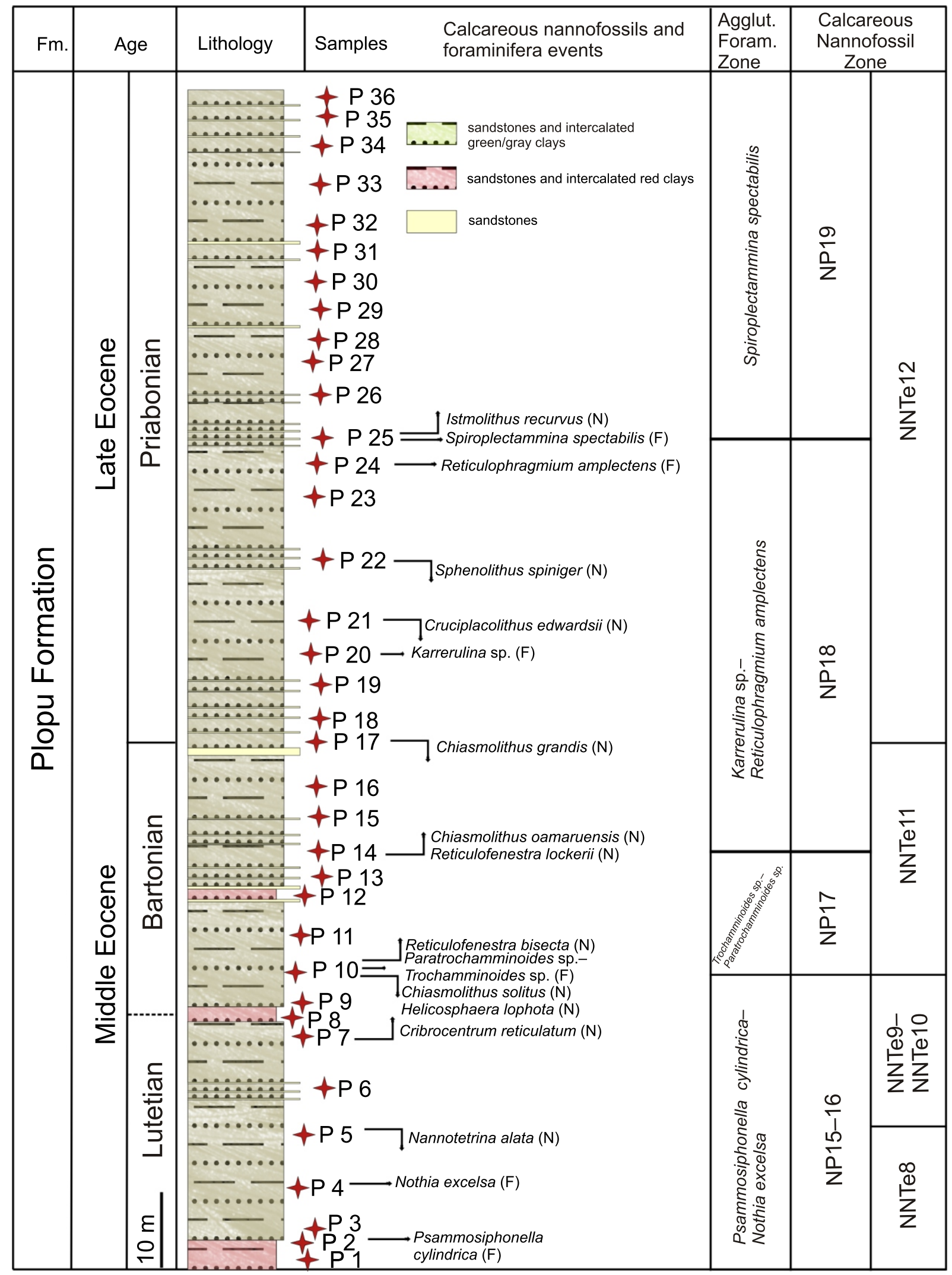

Fig. 3. Sedimentary log and biostratigraphy of the Brodina section

The biostratigraphy used the biozonation schemes of Martini (1971) and Varol (1998) for calcareous nannofossils (N) and of Kaminski et al. (1989), Kaminski (2005) and Bratu (1975) for foraminifera (F) 
listed in Appendix 2. The distribution of foraminifera within the studied samples can be observed in the Appendix 3. The method used for determination of the calcium carbonate content consisted of the following steps: the sample was treated with hydrochloric acid, the resulted volume of the carbon dioxide was measured, and the equivalent percentage of calcium carbonate content was calculated (STAS 7107/3-74, 1974).

The lithological logs were drawn using the StratDraw program (Hoelzel, 2004), while the abundance graphics were generated by the GpalWin application (Goeury, 1997).

\section{RESULTS}

\section{PRESERVATION, SPECIES DIVERSITY AND ABUNDANCE}

Foraminiferal assemblages are quite abundant in the section studied, while preservation of the individuals varies from moderate to good. 119 species of foraminifera (Appendix 1) were identified, the agglutinated foraminifera group being the most abundant (Appendix 1). The diversity index (Hulbert index) varies from 5 to 22.4 in the foraminiferal assemblages (Fig. 4). The most common foraminifera are Psammosiphonella cylindrica, Karrerulina spp., Spiroplectammina spectabilis, Trochamminoides spp., Paratrochamminoides spp., Recurvoides spp., Saccammina placenta, Reophax spp., and Reticulophragmium amplectens, which occur in different proportions (Fig. 5). The diversity of the foraminiferal assemblages correlates with the $\mathrm{CaCO}_{3}$ content of the samples along the section studied (Fig. 4).

Fifty-six calcareous nannofossil species were identified (Fig. 6). Diversity varies between 0 and 2.6 (Shannon_H index). The preservation is moderate to poor and the assemblages are dominated by Noelaerhabdaceae, such as: Reticulofenestra dictyoda (12-58\%), R. bisecta (2-9\%), R. scrippsae (1-15\%), and Cribrocentrum reticulatum (0.3-26.3\%), followed by Coccolithaceae: Coccolithus pelagicus (4-17\%), C. formosus $(0.3-17 \%)$, and C. eopelagicus (3-13\%). Helicosphaeraceae and nannoliths are other important groups: Discoasteraceae, Braarudosphaeraceae, and Sphenolithaceae (Appendix 2). Some species (i.e. Chiasmolithus spp., Clausicoccus fenestratus, Discoaster spp., Lanternithus minutus, Micrantolithus spp., Pontosphaera spp., Sphenolithus spp., Zigrhablithus bijugatus) occur irregularly along the section (Fig. 6). The relative abundance of calcareous nannofossils is low in the samples with low values of $\mathrm{CaCO}_{3}$, probably due to dissolution processes. Blaj et al. (2009) described a similar situation from the near-equatorial Pacific (Ocean Driling Program Site 1218), where the relative abundance of calcareous nannofossils is strongly controlled by the $\mathrm{CaCO}_{3}$ content. The intervals with low $\mathrm{CaCO}_{3}$ content are dominated by the dissolution-resistant species, such as Coccolithus pelagicus or Cyclicargolithus floridanus, similarly to the samples studied (Fig. 7).

\section{BIOSTRATIGRAPHY}

The calcareous nannofossil assemblages document the age of the deposits. A series of bioevents were recorded in the samples studied (Fig. 3). The most important are:

- LO (last occurrence) of Nannotetrina alata (in sample 5) marking the NNTe8/NNTe9 boundary;
- LO of Chiasmolithus solitus (in sample10) marking the NP16/NP17 and NNTe10/NNTe11 boundaries;

- FO (first occurrence) of Chiasmolithus oamaruensis (in sample 14) marking the NP17/NP18 boundary;

- LO of Chiasmolithus grandis (in sample 17) marking the NNTe11/NNTe12 boundary and Middle to Late Eocene transition;

- FO of Istmolithus recurvus (in sample 25) marking the NP18/NP19 boundary.

In addition, some other bioevents have been identified along the section studied:

- FO of Cribrocentrum reticulatum (in sample 7);

- LO of Helicosphaera lophota (in sample 10);

- FO of Reticulofenestra bisecta (in sample 10);

- FO of Reticulofenestra lockerii (in sample 14);

- LO of Cruciplacolithus edwardsii (in sample 21);

- LO of Sphenolithus spiniger (in sample 22).

Based on these bioevents, the section studied falls in the Middle to Late Eocene, NP15-NP19 biozone (Martini, 1971), which corresponds to NNTe8-NNTe12 zones in the biozonation scheme of Varol (1998).

The foraminiferal assemblages complete the biostratigraphical data provided by the calcareous nannofossil assemblages. The base of the section contains planktonic foraminifera, e.g., Subbotina linaperta (Finlay), and Morozovelloides lehneri (Cushman and Jarvis). The assemblage is not diverse but it is indicative of the Middle Eocene.

Based on the total ranges and relative abundances of agglutinated foraminifera, four assemblages were separated on the interval studied (Fig. 5):

- Psammosiphonella cylindrica-Nothia excelsa (Middle Eocene, corresponding to the NP15-NP16 biozones);

- Paratrochamminoides spp.-Trochamminoides spp. (Middle Eocene, corresponding to the NP17 Biozone);

- Karrerulina spp.-Reticulophragmium amplectens (Upper Eocene, corresponding to the NP18 Biozone);

- Spiroplectammina spectabilis (Upper Eocene, corresponding to the NP 19 Biozone).

The agglutinated foraminifera biozonation used follows the Eocene to Oligocene scheme of Kaminski (2005) and Kaminski et al. (1989) for the North Atlantic and Western Tethys, and the Maastrichtian to early Oligocene scheme of Bratu (1975) for the Eastern Carpathians. The foraminiferal biozones were established by acmes or local stratigraphic ranges (Fig. 3).

The absence of index planktonic foraminifera prevented the application of the standard biozonation schemes (Berggren et al., 1995) and consequently the correlation between calcareous nannofossils and foraminifera.

The Middle Eocene Psammosiphonella cylindrica-Nothia excelsa and Paratrochamminoides spp.-Trochamminoides spp. (Figs. 8 and 9) assemblages are characterized by high abundances of the nominal species.

Two stratigraphically important species, Reticulophragmium amplectens and Spiroplectammina spectabilis (Fig. 10), are present in the section studied. $R$. amplectens is one of the markers of the Eocene, ranging in the Carpathians from the Early to Late Eocene (Morgiel and Olszewska, 1981). A peak in Karrerulina spp. can be observed just above the Middle-Late Eocene transition (Fig. 5). A peak in the relative abundance of Spiroplectammina spectabilis occurs in sample 25 (at the base of the NP 19 Zone; Fig. 5), reaching $52 \%$ of the assemblage. 


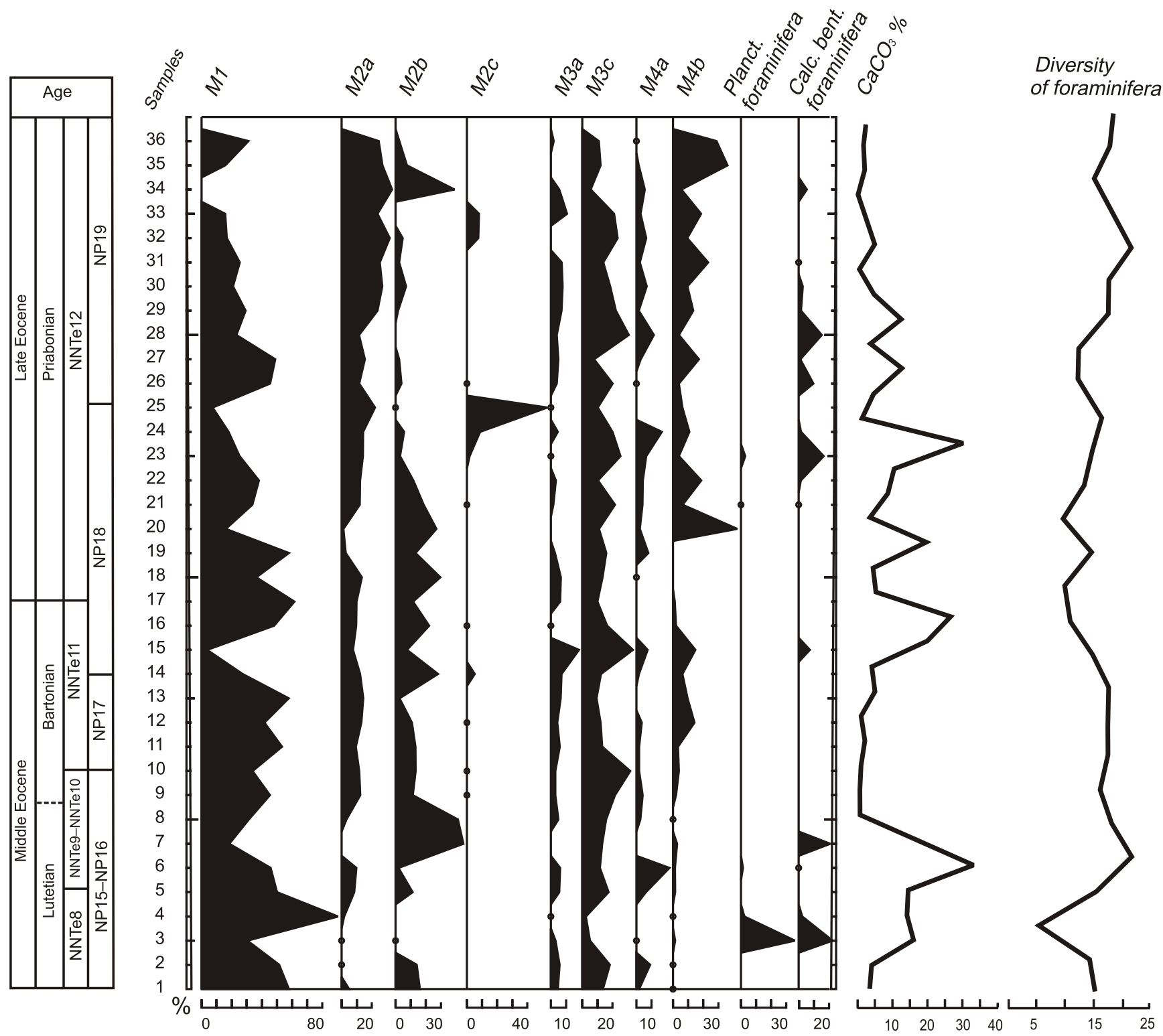

Fig. 4. Distribution (in percentages) of the agglutinated foraminifera morphogroups (M1 - tubular; M2a - globular; M2b - rounded trochospiral and streptospiral/planconvex trochospiral; M2c-elongate keeled; M3a-flattened trochospiral/ flattened planispiral and streptospiral; M3c - flattened streptospiral; M4a - rounded planispiral; M4b - elongate subcylindrical/elongate tapered), planktonic foraminifera (in percentages), calcareous benthic foraminifera (in percentages), $\mathrm{CaCO}_{3}$ content and diversity (Hurlbert index)

\section{PALAEOECOLOGY}

Except for the flattened irregular Ammolagena specimens (M3b), all the morphogroups of agglutinated foraminifera described by Nagy et al. (1995), Van der Akker et al. (2000), Kaminski and Gradstein (2005), Cetean et al. (2011), Murray et al. (2011), and Setoyama et al. $(2011,2013)$ are present in the section investigated. The graphic distribution of the morphogroups (Fig. 4) reveals several events along the section:

- a dominance of tubular foraminifera (M1) in sample 4;

- a negative correlation between the trocho-, streptospiral (M2b), and elongated (M4b) versus tubular forms (M1) in samples $7,8,20$, and 34 ;

- peaks of elongated forms (M4b) in sample 20, and of elongated keeled forms (M2c) in sample 25.
Except for the intervals containing samples 19 and 27, an increase of infaunal M2a and M4b morphotypes and the peak of epifaunal M2c morphotype characterize the Late Eocene.

High abundances of Karrerulina spp. and Recurvoides spp. (M2b and M4b morphogroups) can be observed just above the transition between the Middle and Late Eocene strata (Fig. 4), followed by a peak of Spiroplectammina spectabilis (M2c shallow taxa).

A cooling episode is highlighted by a decrease in the relative abundance of Reticulofenestra scrippsae, Coccolithus formosus, and the nannoliths group, together with an increase in the relative abundance of Reticulofenestra bisecta and Cribrocentrum reticulatum (Fig. 7) from the lower to the upper part of the section. 

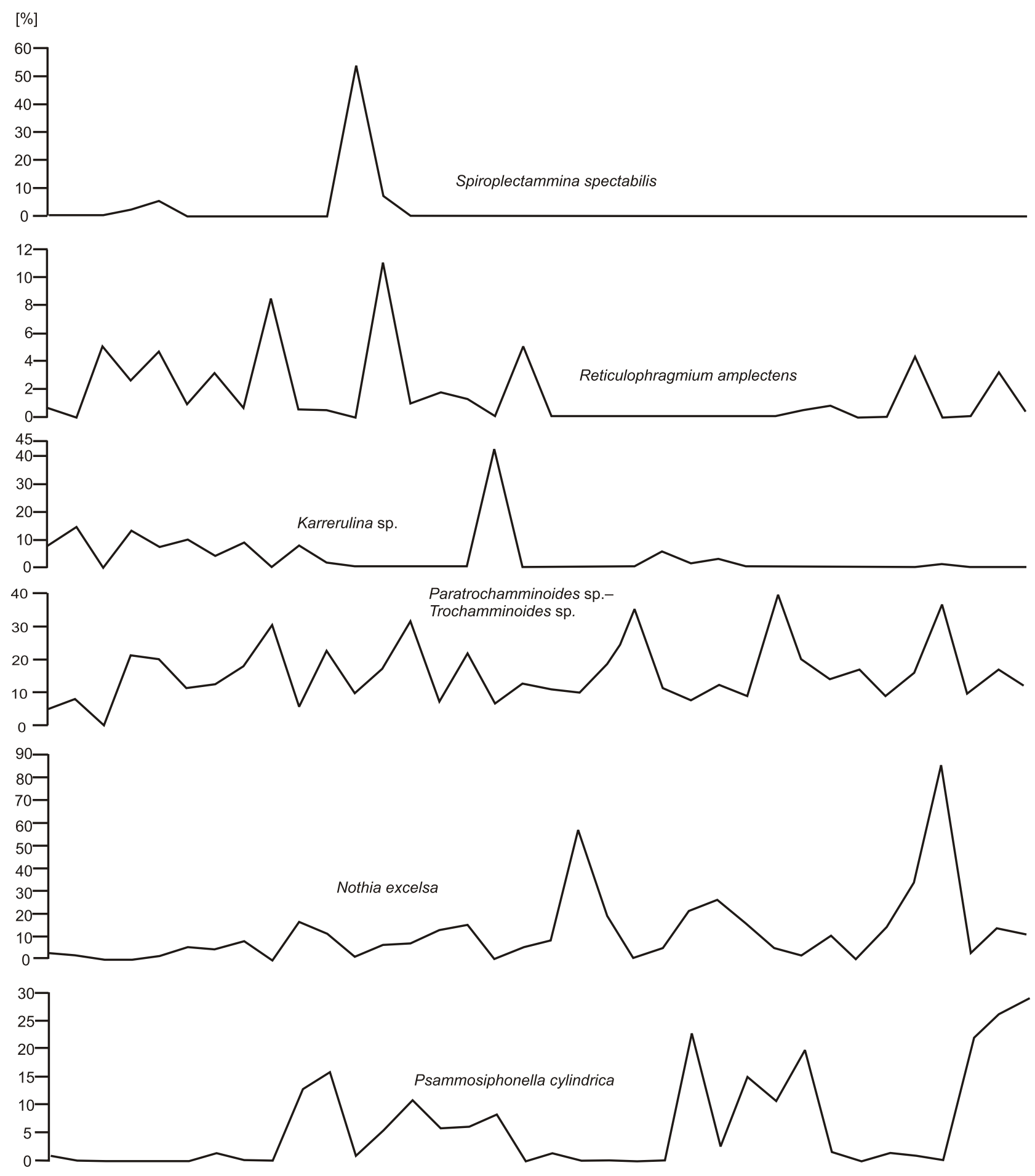

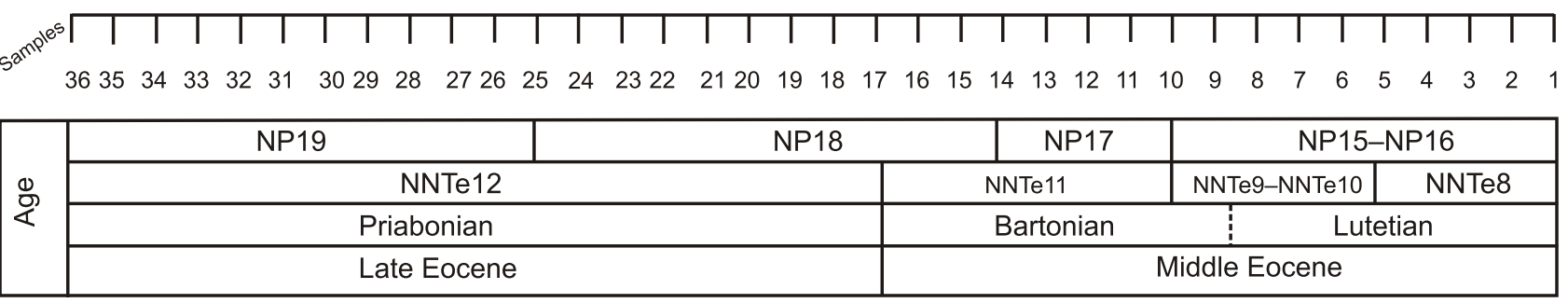

Fig. 5. Relative abundances of characteristic foraminiferal taxa in the Middle to Late Eocene strata of the Plopu Formation from the Suceava River valley 


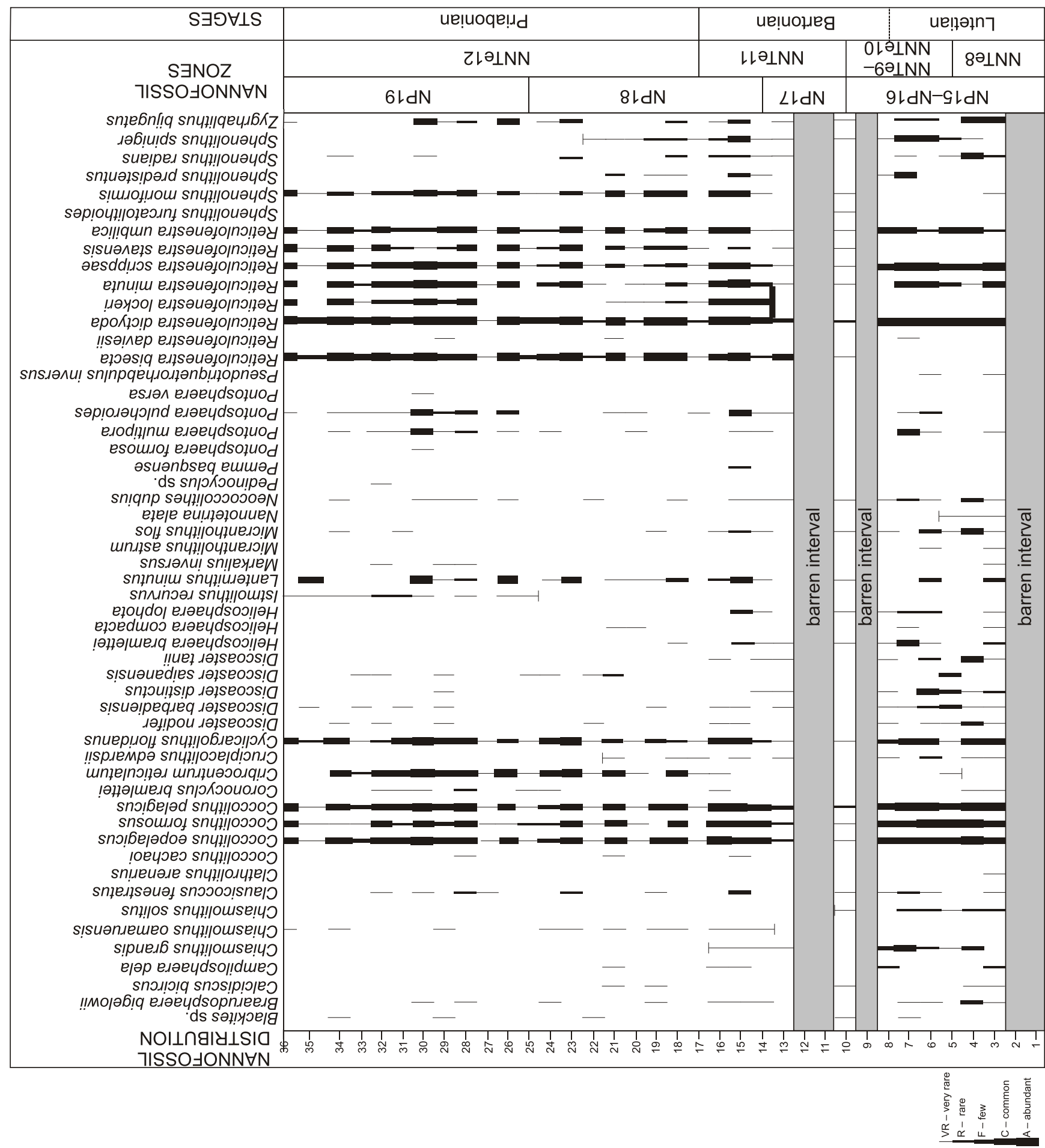




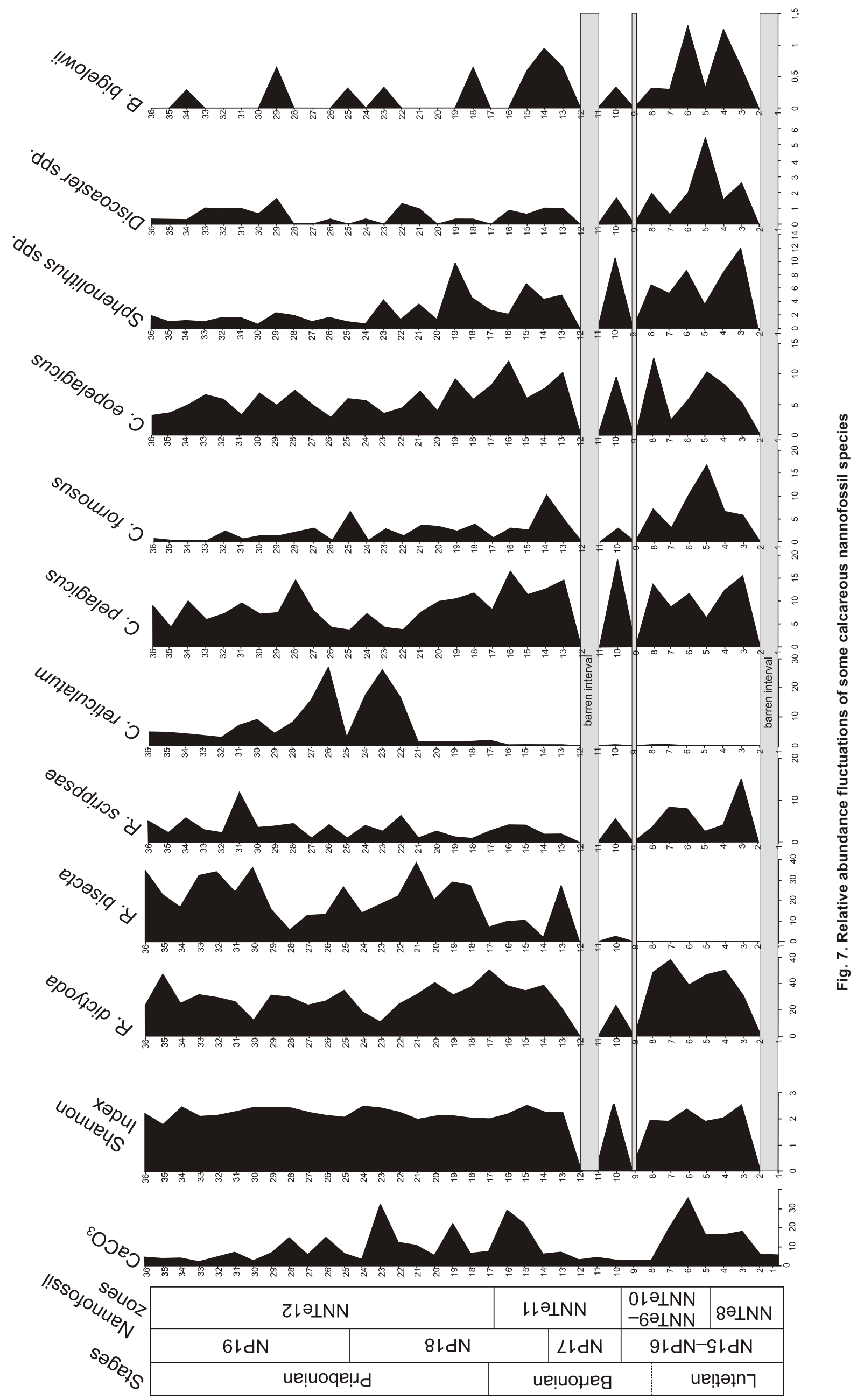




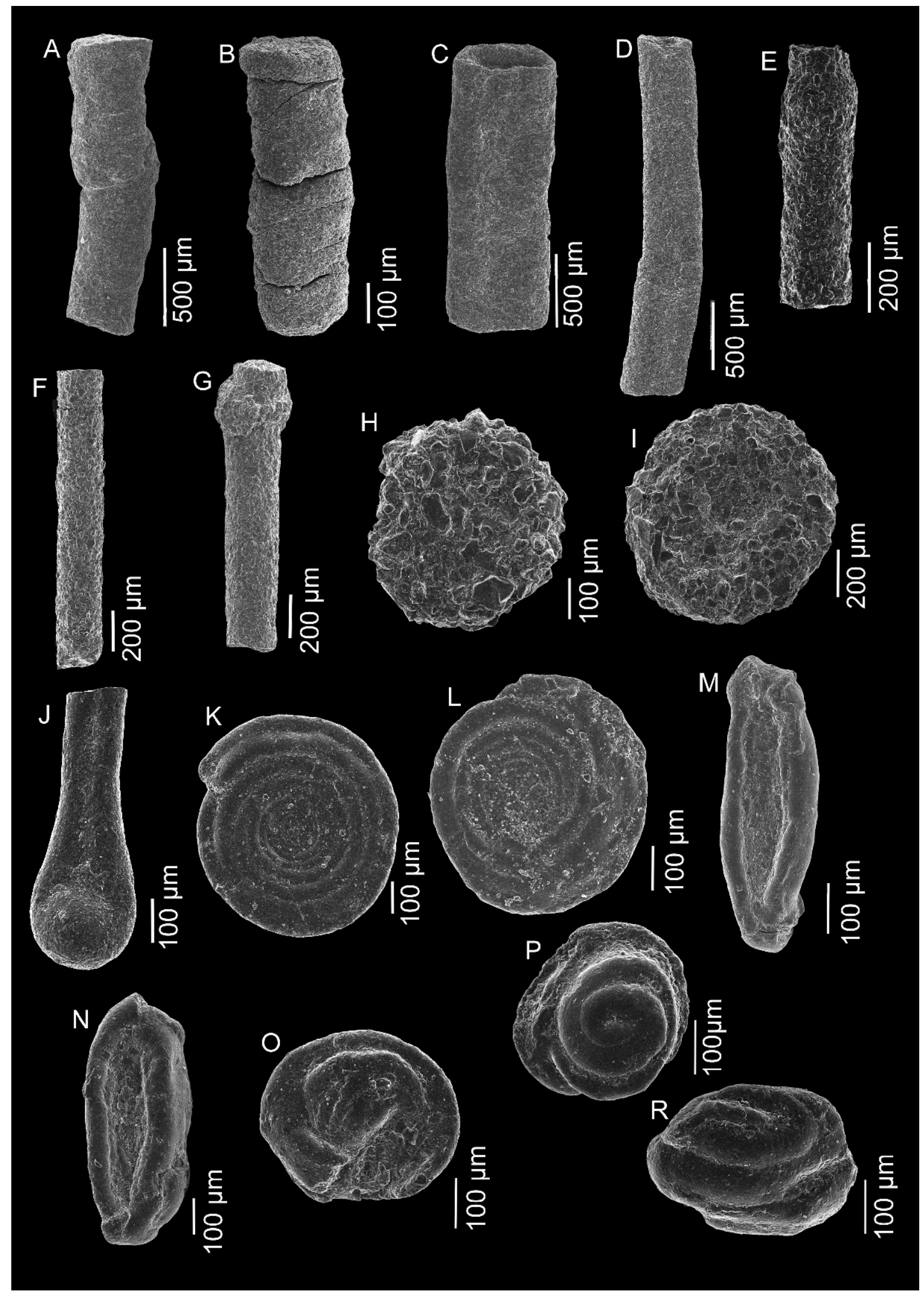

Fig. 8A - Bathysiphon sp. 1 (sample 1); B - Bathysiphon sp. 2 (sample 11); C - Bathysiphon sp. 3 (sample 16); D Nothia excelsa (Grzybowski) (sample 17); E - Psammosiphonella discreta (Brady) (sample 27); F Psammosiphonella cylindrica (Glaessner) (sample 27); G - Rhabdammina linearis Brady (sample 19); H Psammosphaera irregularis (Grzybowski) (sample 19); I - Psammosphaera irregularis (Grzybowski) (sample 20); JHyperammina elongata Brady (sample 6); K - Ammodiscus cretaceus (Reuss) (sample 9); L - Ammodiscus sp. (sample 18); M, N-Ammodiscus peruvianus Berry (M - sample 13, N - sample 22); O - Glomospira sp. (sample 30); $\mathrm{P}, \mathrm{R}$ - Glomospira charoides (Jones \& Parker) (P - sample 22, R - sample 31) 


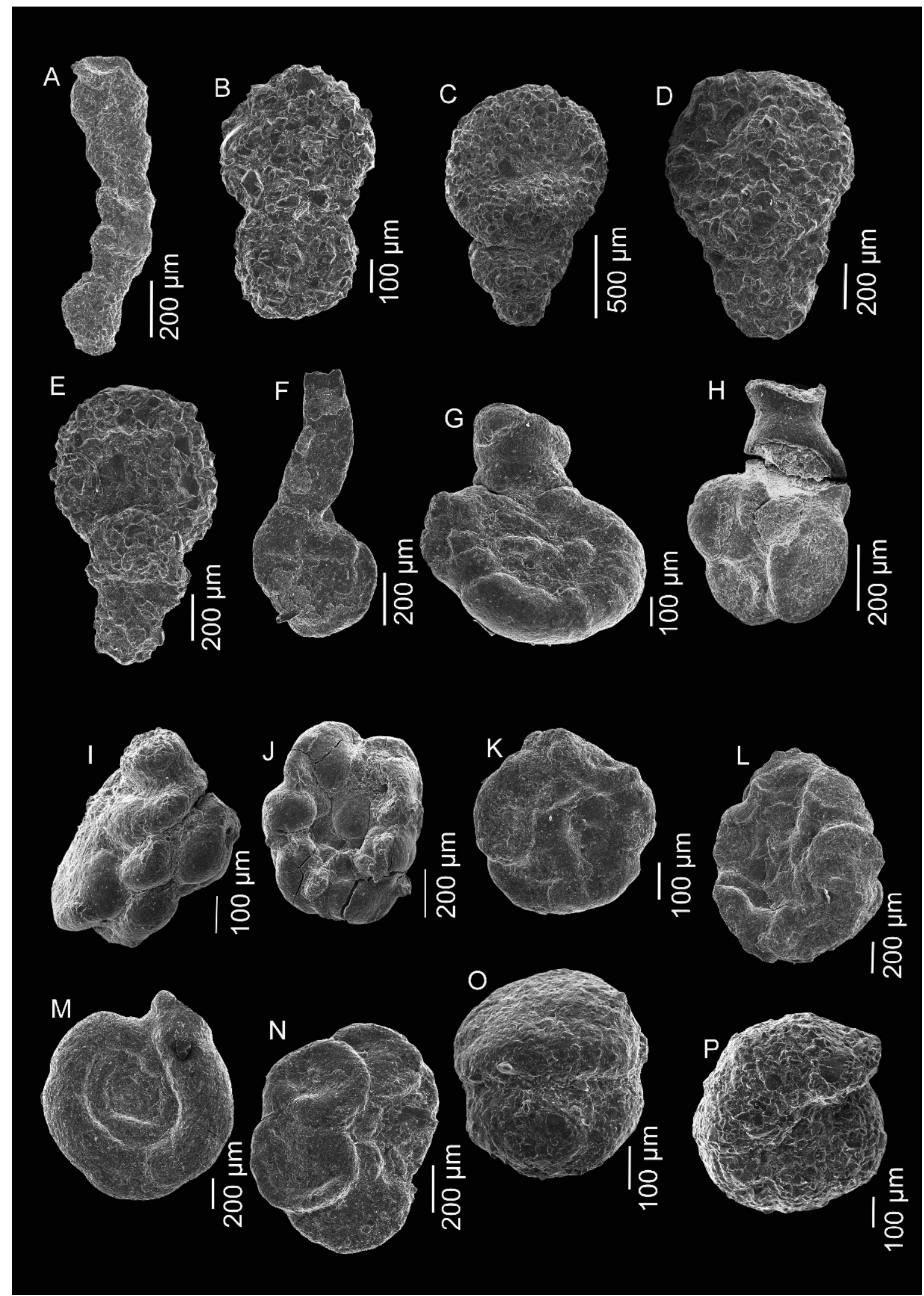

Fig. 9A - Subreophax scalaris (Grzybowski) (sample 31); B - Reophax duplex Grzybowski - (sample 22); C-E Hormosina trinitatensis Cushman \& Renz (C - sample 25, D - sample 27, E - sample 29); F - Lituotuba lituiformis (Brady) (sample 31); G, H- Paratrochamminoides heteromorphus (Grzybowski) (G - sample 10, H - sample 13); I, J Paratrochamminoides acervulatus (Grzybowski) (I - sample 10, J - sample 11); K - Paratrochamminoides sp. 1 (sample 2); L - Paratrochamminoides sp. 2 (sample 10); M - Trochamminoides dubius (sample 9); N Trochamminoides subcoronatus (Grzybowski) (sample 10); 0 - Praesphaerammina subgaleata (Vašiček) (sample 6); P - Recurvoides sp. (sample 5) 


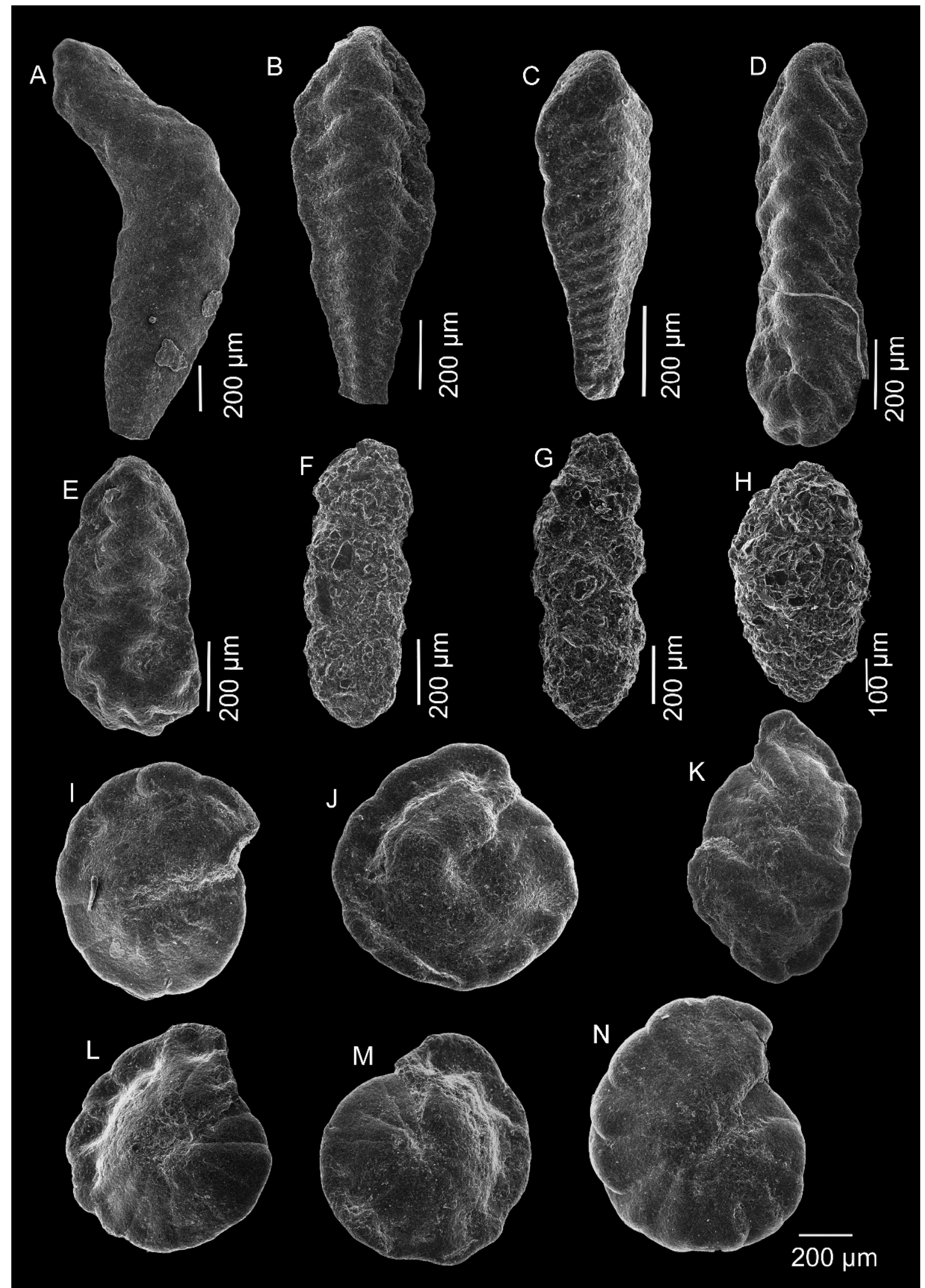

Fig. 10A-E - Spiroplectammina spectabilis (Grzybowski) (sample 25); F, G - Karrerulina horrida (Mjatliuk) (F sample 20, G - sample 29); H - Karrerulina coniformis (Grzybowki) (sample 35); I-N - Reticulophragmium amplectens (Grzybowski) (sample 24) 


\section{DISCUSSION}

\section{BIOSTRATIGRAPHY}

Based on the foraminifera and calcareous nannofossil assemblages, some authors (Ionesi, 1967; Dicea, 1974; Dicea and Dicea, 1976, 1980; Juravle, 2007; Juravle et al., 2008) considered the Plopu Formation as Late Eocene (Priabonian), while others (Joja et al., 1963; Agheorghiresei et al., 1967; Săndulescu et al., 1987; Bădescu, 2005) claimed that the Middle/Late Eocene (Bartonian/Priabonian) boundary is observed in this unit. The section studied is representative for this long-time age discussion; the results obtained supporting the second theory based on micropalaeontological assemblages. Thus, a revision of the lithostratigraphical units from the northern part of the Tarcău Nappe is necessary. Based on larger benthic foraminifera, the Bartonian/Priabonian boundary was traced at the first occurrence of Nummulites fabianii, Assilina alpina, Discocyclina pratti minor, and Asterocyclina alticostata danubica (Papazzoni and Sirotti, 1995; Serra-Kiel et al., 1998; Ionesi, 1999; Bassi et al., 2000). From the calcareous nannofossils point of view, the boundary between the Bartonian and Priabonian is placed within the basal part of the NP18 zone, based on the LO of Chiasmolithus grandis (Varol, 1998) and/or at the lowest occurrence of Chiasmolithus oamaruensis (Berggren et al., 1985, 1995). These events were used to approximate the Bartonian/Priabonian boundary, being consistent with the results obtained in the Priabonian stratotype and parastratotype at Bressana (Verhallen and Romein, 1983).

The Paratrochamminoides spp.-Trochamminoides spp. (Fig. 9) assemblages have been noticed in the Middle Eocene deposits of the Outer Carpathians in Poland (Kender et al., 2005). These assemblages are known to make acmes at different times: Morgiel and Szymakowska (1978) placed the event in the earliest Eocene, Morgiel and Olszewska (1981) in the Paleocene of the Polish Carpathians, while Kaminski et al. (1996) reported such an event from the Late Cretaceous of the Numidian Rif. The Reticulophragmium amplectens abundance defines the Middle Eocene $R$. amplectens Zone mentioned by Joja et al. (1963), Agheorghiresei at al. (1967), Bratu (1975), and Săndulescu et al. (1987) in the Romanian Carpathians, and by Geroch and Nowak (1984) in the Polish Carpathians. Gradstein et al. (1994) extended the range of the $R$. amplectens Zone into the late Eocene for the North Sea and Labrador Shelf. This species was observed in all samples studied, with the highest proportion in sample $24(11 \%)$. The Karrerulina spp. acmes were mentioned at different stratigraphic intervals: Gradstein et al. (1994) and Kaminski et al. (1996) reported it from the upper part of the Lower Eocene; Bąk (2004) and Bindiu and Filipescu (2011) from the Lower Eocene, just above the Glomospira acme; while Kaminski (2005) from the lower part of the Middle Eocene. In the Romanian Eastern Carpathians, Bratu (1975) mentioned a peak of Spiroplectammina spectabilis in the Bisericani Formation, which is an equivalent of the Plopu Formation. This taxon was mentioned to form acmes just above the Cretaceous/Paleogene boundary in Gubbio, southern Spain, and in the equatorial Atlantic (Kuhnt and Kaminski, 1996, Kuhnt et al., 1998) in the Paleocene deposits from the Central North Sea basin and Labrador Shelf (Gradstein et al., 1994). This almost monospecific assemblage has been reported from Late Eocene deposits from Atlantic and western Tethyan regions (Kaminski et al., 1989; Kaminski, 2005).
PALAEOECOLOGY

The distribution of morphogroups shows a low organic matter flux and moderate oxygenation during the Middle Eocene (dominance of the morphotype M1), and alternating eutrophic (low oxygenation) - oligotrophic (relatively well-oxygenated) intervals around the Middle/Late Eocene transition (reflected by a negative correlation of M2b + M4b with M1). The increased bottom current activity and bottom water oxygenation are defined by intervals with epifaunal and infaunal opportunists, according to Kaminski and Schroder (1987) and Kaiho (1994).

The four assemblages of foraminifera offer the following palaeoecological information: the Psammosiphonella cylindrica-Nothia excelsa (Fig. 9) assemblage suggests relatively low organic matter flux and moderately oxygenated bottom waters (Table 1), while the Paratrochamminoides spp.-Trochamminoides spp. assemblage points to a lower-energy deep-water environment with low sedimentation rates. The Psammosiphonella cylindrica-Nothia excelsa (Fig. 8) and Paratrochamminoides spp.-Trochamminoides spp. (Fig. 9) assemblages are common in bathyal deposits (Schröder, 1986; Nagy et al., 1995).

The abundance of the Karrerullina spp. in sample 20 suggests an increase in the organic matter flux (Kaminski, 2005). The Spiroplectammina spectabilis taxa is known to be an opportunistic "disaster species" related to the trophic continuum (Kaminski and Gradstein, 2005); in the Atlantic and western Tethyan regions (Kaminski et al., 1989; Kaminski, 2005) and an acme of Spiroplectammina spectabilis was related to eutrophic conditions (Kaminski and Gradstein, 2005).

Tubular forms (such as Psammosiphonella cylindrica, Nothia spp., Bathysiphon sp.), as well as globular (Saccammina spp., Psammosphaera spp.), rounded (Recurvoides spp., Reticulophragmium spp.) or flattened streptospiral ones (Paratrochamminoides spp., Trochamminoides spp.), together with coarsely agglutinated taxa are typical of the "flysch-type" agglutinated foraminiferal biofacies (Gradstein and Berggren, 1981; Kaminski and Gradstein, 2005). The composition of the microfossil assemblages, associated with variable $\mathrm{CaCO}_{3}$ content in all of the samples, indicates an upper bathyal depositional environment with frequent oscillations of the CCD. This is consistent with the hypothesis of Miller et al. (1982) that the flysch-type agglutinated assemblages are not restricted only to environments placed below the CCD.

The different values of the foraminiferal diversity index suggest changes in the palaeoenvironmental conditions.

Based on the distribution of the agglutinated foraminiferal morphogroups and assemblages, a sea level drop and a cooling interval are suggested. This is consistent with the already known change between the warm Middle Eocene to the cool Late Eocene (Keller et al., 1987; Gedl and Garecka, 2008).

The calcareous nannofossil assemblages (Fig. 11) also suggest a cooling trend along the section (Table 1). Even if the cold-water taxa (chiasmoliths, Istmolithus recurvus, Reticulofenestra daviesii) are not present in high numbers, a cooling episode can be inferred due to a drop in the abundance of warm-water taxa. The Middle Eocene oligotrophic conditions and warm waters are indicated by the following taxa: Discoaster spp., Sphenolithus spp. (S. moriformis being an exception), and Helicosphaera compacta (Bralower, 2002; Agnini et al., 2006; Bown and Pearson, 2009). This cooling trend was revealed by several other authors (e.g., Edwards and Perch-Nielsen, 1975; Beckmann et al., 1981; Wei and Wise, 1990; Oszczypko-Clowes, 2001; Bralower, 2002; Melinte, 2005; Agnini et al., 2006, 2007; Bown and Pearson, 2009; Cascella and Dinares-Turell, 2009). 
Palaeoecological affinities of the main species identified

\begin{tabular}{|c|c|c|}
\hline $\begin{array}{l}\text { Species\General } \\
\text { Group }\end{array}$ & Palaeobathymetry, palaeoecology, temperature & References \\
\hline \multicolumn{3}{|l|}{ Foraminifera } \\
\hline Psammosiphonella cylindrica & Bathyal to abyssal, low organic matter flux & Kaminski and Gradstein (2005) \\
\hline Nothia excelsa & Bathyal to abyssal, low organic matter flux & \\
\hline $\begin{array}{l}\text { Trochamminoides spp. } \\
\text { Paratrochamminoides spp. }\end{array}$ & $\begin{array}{l}\text { Upper bathyal to abyssal, lower energy } \\
\text { deep-water environment, low sedimentary rates }\end{array}$ & $\begin{array}{c}\text { Kender et al. (2005), Setoyama et al. } \\
(2013)\end{array}$ \\
\hline Karrerulina spp. & $\begin{array}{l}\text { Upper bathyal to abyssal, high organic matter } \\
\text { flux }\end{array}$ & $\begin{array}{c}\text { Kaminski and Gradstein (2005), Bindiu } \\
\text { et al. (2013) }\end{array}$ \\
\hline Reticulophragmium amplectens & $\begin{array}{c}\text { Bathyal to abyssal, relatively stable environ- } \\
\text { mental conditions }\end{array}$ & $\begin{array}{c}\text { Kaminski and Gradstein (2005), Kender } \\
\text { et al. (2008) }\end{array}$ \\
\hline Spiroplectammina spectabilis & $\begin{array}{l}\text { Bathyal to abyssal, high organic matter flux, } \\
\text { eutrophic conditions, cool water }\end{array}$ & $\begin{array}{c}\text { Kaminski (1984, 2005), Kaminski et al. } \\
\text { (1989), } \\
\text { Kaminski and Gradstein (2005) }\end{array}$ \\
\hline $\begin{array}{l}\text { Calcareous } \\
\text { Nannofossils } \\
\text { Chiasmolithus sp. } \\
\text { Istmolithus recurvus } \\
\text { Reticulofenestra daviesii }\end{array}$ & Cool- or cold-water taxa & $\begin{array}{c}\text { Bukry (1973), Wei and Wise (1990), } \\
\text { Firth and Wise (1992), Bralower (2002), } \\
\text { Persico and Villa (2004), } \\
\text { Tremolada and Bralower (2004), Villa } \\
\text { and Persico (2006), Villa et al. (2008), } \\
\text { Oszczypko-Clowes and Żydek (2012) }\end{array}$ \\
\hline $\begin{array}{l}\text { Coccolithus formosus } \\
\text { Discoaster sp. } \\
\text { Helicosphaera sp. } \\
\text { Sphenolithus sp. }\end{array}$ & Warm-water taxa & $\begin{array}{l}\text { Wei and Wise (1990), Aubry (1992a,b), } \\
\text { Wei et al. (1992), Kelly et al. (1996), } \\
\text { Bralower (2002), Kahn and Aubry } \\
\text { (2004), Tremolada and Bralower (2004), } \\
\text { Gibbs et al. (2006), Villa et al. (2008), } \\
\text { Oszczypko-Clowes and Żydek (2012) }\end{array}$ \\
\hline
\end{tabular}

\section{CONCLUSIONS}

Foraminifera and calcareous nannofossil assemblages revealed new biostratigraphical and palaeoenvironmental data for the Plopu Formation in the northern part of the Tarcău Nappe, Eastern Carpathians.

Biostratigraphic data assigned the section studied to the following biozones:

- NP15-NP16 zones (corresponding with Psammosiphonella cylindrica-Nothia excelsa foraminiferal assemblage - Middle Eocene);

- NP17 Zone (corresponding with Paratrochamminoides spp.-Trochamminoides spp. assemblage - Middle Eocene);

- NP18 Zone (corresponding with Karrerulina spp.-Reticulophragmium amplectens assemblage - Late Eocene);

- NP 19 Zone (Spiroplectammina spectabilis assemblage - Late Eocene). These correspond with the NNTe8-NNTe12 biozones.

Thus, it was demonstrated that the Middle-Late Eocene transition is located within the Plopu Formation.

The foraminiferal assemblages are dominated by agglutinated taxa; planktonic and calcareous benthic forms occur sporadically and suggest environments placed above the CCD. The foraminiferal assemblages suggest an upper bathyal setting with hemipelagic deposition, palaeoenvironmental instabil- ity, oscillations of the CCD, and normal salinity, as part of a "flysch-type" biofacies.

The calcareous nannofossil together with the foraminiferal assemblages indicate a warm period with low organic matter flux and moderate oxygenation during the Middle Eocene, followed by a cooling episode with increasing organic matter and siliciclastic flux during the Late Eocene.

Palaeoenvironmental instability is suggested by the distribution of the agglutinated morphogroups, the foraminifera diversity, the calcareous nannofossil assemblages, and the $\mathrm{CaCO}_{3}$ content which correlate along the section studied.

Acknowledgements. This paper is a result of a doctoral research made possible by the financial support of the Sectoral Operational Programme for Human Resources Development 2007-2013, co-financed by the European Social Fund, under the project POSDRU/159/1.5/S/133391 - "Doctoral and postdoctoral excellence programs for training highly qualified human resources for research in the fields of Life Sciences, Environment and Earth". The senior author also gratefully acknowledges support from the "B.J. O'Neill Scholarship" of the Grzybowski Foundation. The fieldwork and additional research costs were supported by S.N.G.N ROMGAZ. R.B. and D.G. thanks to CNCSIS-UEFISCSU, project PN II-RU_TE_ 313/2010 and PN-II-PT-PCCA-2013-4-0297 for the financial support. Sincere thanks go to M. Kaminski, M. Oszczypko-Clowes, and an anonymous reviewer for their critical comments and suggestions, which helped us to improve the manuscript. 

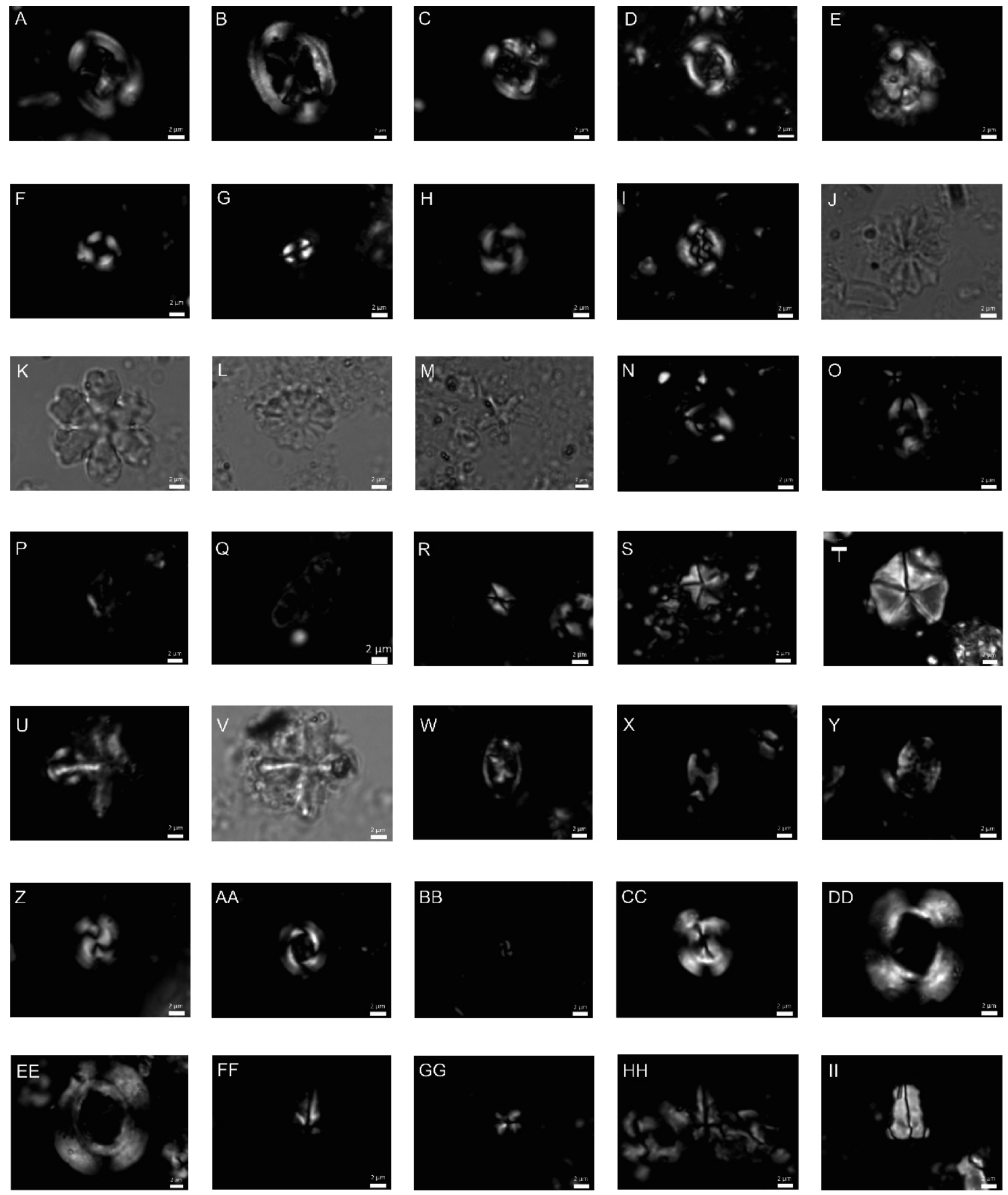

Fig. 11. Calcareous nannofossils from Brodina Valley section

A - Chiasmolithus eoaltus - sample 7; B - Chiasmolithus grandis - sample 14; C - Chiasmolithus oamaruensis - sample 14; D Chiasmolithus solitus - sample 5; E - Coccolithus eopelagicus - sample 21; F - Coccolithus formosus - sample 10; G - Coccolithus pelagicus - sample 32; H - Cribrocentrum reticulatum - sample 22; I-Cruciplacolithus edwardsii - sample 17; J - Discoaster barbadiensis sample 5; K - Discoaster deflandrei - sample 10; L - Discoaster saipanensis - sample 7; $\mathbf{M}$ - Discoaster tani - sample 7; $\mathbf{N}$ - Helicosphaera bramlettei - sample 8; O - Helicosphaera compacta - sample 4; P - Helicosphaera lophota - sample 4; Q - Isthmolithus recurvus - sample 27; $\mathbf{R}$ - Lanternithus minutus - sample 34; S - Micrantholithus breviradiatus - sample 7; T - Micrantholithus flos - sample 30; U, V Nannotetrina alata - sample 4; W - Neococcolithes dubius - sample 22; $\mathbf{X}$ - Pontosphaera exilis - sample 3; Y - Pontosphaera multipora sample 30; Z - Reticulofenestra bisecta - sample 20; AA - Reticulofenestra dictyoda - sample 16; BB - Reticulofenestra minuta - sample 18; CC - Reticulofenestra stavensis - sample 16; DD, EE - Reticulofenestra umbilica - sample 7 and 27; FF - Sphenolithus furcatolithoides - sample 7; GG - Sphenolithus moriformis - sample 31; HH - Sphenolithus radians - sample 6; II - Zygrablithus bijugatus - sample 5; the photographs taken under cross-polarized light; scale bar $-2 \mu \mathrm{m}$ 


\section{REFERENCES}

Agheorghiresei, V., Băncilă, I., Costea, I., Roşca, A., 1967 Contribuţii la stratigrafia Flişului Carpatic (in Romanian). Dări de Seamă ale Comitetului Geologic, 53: 251-273.

Agnini, C., Muttoni, G., Kent, D.V., Rio, D., 2006. Eocene biostratigraphy and magnetic stratigraphy from Possagno, Italy: the calcareous nannofossil response to climate variability. Earth and Planetary Science Letters, 241: 815-830.

Agnini, C., Fornaciari, E., Rio, D., Tateo, F., Backman, J., Giusberti, L., 2007. Responses of calcareous nannofossil assemblages, mineralogy and geochemistry to the environmental perturbations across the Paleocene/Eocene boundary in the Venetian Pre-Alps. Marine Micropaleontology, 63: 19-38.

Armstrong, H.A., Brasier, M.D., 2005. Microfossils (Second Edition). Blackwell Publishing, Oxford.

Athanasiu, S., Macovei, G., Atanasiu, I., 1927. La Zone Marginale du Flysch dans la partie inferieure du Bassin de la Bistrita. Guide de Excurssion: 315-352. Association Géologique Carpato-Balkanique, Bucharest.

Aubry, M.P., 1992a. Paleogene calcareous nannofossils from the Kerguelen Plateau, Leg 120. Proceedings of the Ocean Drilling Program, Scientific Results, 120: 471-491.

Aubry, M.P., 1992b. Late Paleogene nannoplankton evolution: a tale of climatic deterioration. In: Eocene-Oligocene Climatic and Biotic Evolution (eds. D.R. Prothero and W.A. Berggren): 272-309. Princeton Univ. Press, Princeton.

Bąk, K., 2004. Deep-water agglutinated foraminiferal changes across the Cretaceous/Tertiary and Paleocene/Eocene transition in the deep flysch environment; eastern Carpathians (Bieszczady Mts, Poland). Grzybowski Foundation Special Publication, 8: 1-56.

Bassi, D., Čosovič, V., Less, G., Mietto, P., Papazzoni, C.A. Trevisani, E., Ungaro, S., 2000. Biostratigraphy and palaeoecology at the Middle-Upper Eocene boundary: The Venetian Area. Annali dell'Universita di Ferrara, 8 (Supplement): 41-93.

Bădescu, D., 2005. Evoluţia Tectono-Stratigrafică a Carpaţilor Orientali în decursul Mezozoicului şi Neozoicului (in Romanian). Editura Economică, Bucureşti.

Beckmann, J.P., Bolli, H.M., Perch-Nielsen, K., Decima, F.P., Saunders, J.B., Toumarkine, M., 1981. Major calcareous nannofossil and foraminiferal events between the Middle Eocene and Early Miocene. Palaeogeography, Palaeoclimatology, Palaeoecology, 36: 155-190.

Berggren, W.A., Kent, D.V., Flynn, J.J., 1985. Palaeogene geochronology and chronostratigraphy. Geological Society Memoir, 10: $141-195$

Berggren, W.A., Kent, D.V., Swisher III, C.C., Aubry, M.-P., 1995 A revised Cenozoic geochronology and chronostratigraphy SEPM Special Publication, 54: 129-212.

Bindiu, R., Filipescu, S., 2011. Agglutinated Foraminifera from the Northern Tarcău Nappe (Eastern Carpathians, Romania). Studia UBB Geologia, 56: 31-41

Bindiu, R., Filipescu, S., Bălc, R., 2013. Biostratigraphy and paleoenvironment of the Upper Cretaceous deposits in the northern Tarcău Nappe (Eastern Carpathians) based on foraminifera and calcareous nannoplankton. Geologica Carpathica, 64: 117-132.

Blaj, T., Backmann, J., Raffi, I., 2009. Late Eocene to Oligocene preservation history and biochronology of calcareous nannofossils from paleo-equatorial ocean sediments. Rivista Italiana di Paleontologia e Stratigrafia, 115: 67-85.

Bown, P., Pearson, P., 2009. Calcareous plankton evolution and the Paleocene/Eocene thermal maximum event: New evidence from Tanzania. Marine Micropaleontology, 71: 60-70.

Bown, P.R., Young, J.R., 1998. Introduction. In: Calcareous Nannofossil Biostratigraphy (ed. P.R. Bown): 1-15. British Micropalaeontology Society Series, Chapman and Hall, London.
Bralower, T.J., 2002. Evidence of surface water oligotrophy during the Paleocene-Eocene thermal maximum: nannofossil assemblage data from Ocean Drilling Program Site 690, Maud Rise, Weddell Sea. Paleoceanography, 17: 13-1-13-15.

Bratu, E., 1975. Coupe du Maestrichtien a l'Oligocéne inferiéure dans le Flysch externe de Cuejdiu (Bassin de la Bistriţa). 14th European Micropaleontological Colloquium, Bucureşti: 135-141.

Bukry, D., 1973. Low-latitude coccolith biostratigraphy zonation Initial Reports of the Deep Sea Drilling Project, 15: 685-704.

Cascella, A., Dinares-Turell, J., 2009. Integrated calcareous nannofossil biostratigraphy and magnetostratigraphy from the uppermost marine Eocene deposits of the southeastern Pyrenean foreland basin: evidences for marine Priabonian deposition. Geologica Acta, 7: 281-296.

Cetean, C., Balc, R., Kaminski, M.A., Filipescu, S., 2011. Integrated biostratigraphy and palaeoenvironments of an upper Santonian - upper Campanian succession from the southern part of the Eastern Carpathians, Romania. Cretaceous Research, 32: 575-590.

Corliss, B.H., 1985. Microhabitats of benthic foraminifera within deep-sea sediments. Nature, 314: 435-438.

Dicea, O., 1974. Studiul Geologic al Regiunii Voronet-Suha Mica-Platonita (in Romanian). Studii tehnice şi economice., seria J, Stratigrafie, 11: 1-143

Dicea, O., Dicea, M., 1976. Limita Oligocen-Eocen în flişul extern din pârâul Larga dupa conţinutul în nannoplancton (in Romanian). Revista Mine Petrol şi Gaze, 27: 185-188.

Dicea, O., Dicea, M., 1980. Stratigraphic correlation on nannoplankton basis in the external flysch of the east Carpathians. Dări de Seamă ale Institutului Geologic si Geofizic, 65: 111-126.

Edwards, A.R., Perch-Nielsen, K., 1975. Calcareous nannofossils from the southern southwest Pacific, Deep Sea Drilling Project, Leg 29. Initial Reports of the Deep Sea Drilling Project, 29 469-539.

Firth, J.V., Wise, Jr., S.W., 1992. A preliminary study of the evolution of Chiasmolithus in the middle Eocene to Oligocene of Sites 647 and 748. Proceedings of the Ocean Drilling Program, Scientific Results, 120: 493-508.

Gedl, P., Garecka, M., 2008. Middle-Late Eocene phytoplankton from marl intraclasts (Podhale Paleogene, Inner Carpathians, Poland): biostratigraphic and paleoenvironmental implications. Geologica Carpathica, 59: 319-332.

Geroch, S., Nowak, W. 1984. Proposal of zonation for the late Tithonian-late Eocene, based upon arenaceous foraminifera from the outer Carpathians, Poland. In: Benthos '83, 2nd International Symposium on Benthic Foraminifera, Pau 1983 (ed. H.J. Oertli): 225-239. Elf Aquitaine, Esso REP, and Total CFP, Pau and Bordeaux.

Gibbs, S.J., Bralower, T.J., Bown, P.R., Zachos, J.C., Bybell, L.M., 2006. Shelf and open-ocean calcareous phytoplankton assemblages across the Paleocene-Eocene Thermal Maximum: implication for global productivity gradients. Geology, $\mathbf{3 4}$ 233-236.

Gigliuto, L. G., Grasu, C., Loiacono, F. Miclaus, C., Moretti, E., Puglisi, D., Raffaelli, G., 2004. Provenance changes and sedimentology of the Eocene-Oligocene "Moldoviţa Lithofacies" of the Tarcău Nappe (Eastern Carpathians, Romania). Geologica Carpathica, 55: 299-309.

Goeury, C., 1997. GpalWin: gestion, traitement et représentation de la paléoécologie. XV-ème Symposium de l'APLF (Association des Palynologues de Langue Française), Université Claude Bernard, Lyon.

Gradstein, F.M., Berggren, W.A., 1981. Flysch-type agglutinated foraminifera and the Maastrichtian to Paleogene history of the Labrador and North Seas. Marine Micropaleontology, 6: 211-268. 
Gradstein, F.M., Kaminski, M.A., Berggren, W.A., D’lorio, M.A. 1994. Cenozoic biostratigraphy of the Central North Sea and Labrador Shelf. Micropaleontology, 40, Supplement: 1-152.

Grasu, C., Catana, C., Grinea, D., 1988. Flişul Carpatic: Petrografie si Consideratii Economice (in Romanian). Editura Tehnica, Bucuresti.

Hoezel, M., 2004. StratDraw: automatic generation of stratigraphic sections from tabulated field data. Computers and Geociences, 30: 785-789.

Hulbert, S. H., 1971. The nonconcept of species diversity: a critique and alternative parameters. Ecology, 52: 577-585.

Ionesi, L., 1967. Contribuţii la stratigrafia flişului paleogen (in Romanian). Analele Ştiinţifice ale Univiversităţii “Al. I. Cuza", Seria Geologie-Geografie, 13: 61-65.

Ionesi, L., 1971. Flişul Paleogen din Bazinul Văii Moldovei (in Romanian). Editura Academiei Române, Bucureşti.

Ionesi, L., 1999. Nummulites des formations Eocennes du Flisch Externe des Carpathes Orientales et leur importance biostratigraphique. Acta Palaeontologica Romaniae, 2: 223-230.

Joja, Th., 1952. Structura geologică a flişului marginal din regiunea Valea Suha Mică şi Suha Mare (in Romanian). Dări de Seamă ale Institutului Geologic, 36: 69-93.

Joja, Th., 1955. Flişul Extern şi Miocenul dintre Facău şi Bilca şi la SV de Voitinelu (in Romanian). Dări de Seamă ale Şedinţelor Comitetului Geologic al Republicii Populare Romane, 39: 86-300.

Joja, Th., 1960. Contribuţiuni la cunoaşterea stratigrafiei şi tectonicii Flişului Extern din jurul comunei Brodina şi de la fundu pârâului Putna (in Romanian). Buletinul Institutului de Petrol, Gaze şi Geologie, 6: 9-25.

Joja, Th., Manoliu, E., 1978. Asupra prezenţei unor macroforaminifere în orizontul calcarului de Pasieczna din flişul eocen de la Gura Putnei pe Valea Sucevei (in Romanian). Studi şi Cercetări Geologice, 23: 103-110.

Joja, Th., Cosma, V., Dumitrescu, Z., 1963. Orizonturile Flişului Extern dintre Suceava şi Suceviţa şi conţinutul lor micropaleontologic (in Romanian). Asociaţia Geologică Carpato-Balcanică. Congresul al V-lea, 3: 221-252.

Joja, Th., lancu, Gh., Popovici, M., 1967. Principalele rezultate de ordin stratigrafic şi tectonic ale forajelor Comitetului Geologic de la Putna (Regiunea Suceava) (in Romanian). Dări de Seamă ale Şedinţelor Comitetului Geologic, 52: 69-93.

Joja, T., Mutihac, V., Alexandrescu, Gr., Bercia, I., 1968. Geological Map of Romania, Rădăuţi sheet 1:200 000. State Geological Committee, Bucharest

Jones, R.W., Charnock, M.A., 1985. "Morphogroups" of agglutinating foraminifera. Their life position and feeding habits and potential applicability in (paleo)ecological studies. Revue de Paleobiologie, 4: 311-320.

Juravle, D.T., 2007. Geologia regiunii dintre Valea Sucevei şi Valea Putnei (Carpaţii Orientali) (in Romanian). Casa Editorială Demiurg, laşi.

Juravle, D.T., Florea, F.F., Bogatu, L., 2008. The importance of calcareous nannoplankton in establishing lithostratigraphic landmarks in the Eocene column of Tarcau Nappe in the Suceava river basin (Obcina Mare). Acta Palaeontologica Romaniae, 6: 145-172.

Kahn, A., Aubry, M.P., 2004. Provincialism associated with the Paleocene/Eocene thermal maximum: temporal constraint. Marine Micropaleontology, 52: 117-131.

Kaiho, K., 1994. Benthic foraminiferal dissolved-oxygen index and dissolved-oxygen levels in the modern ocean. Geology, 22: 719-722.

Kaminski, M.A., 1984. Shape variation in Spiroplectammina spectabilis (Grzybowski). Acta Palaeontologica Polonica, 29: 29-49, plates $12-13$.

Kaminski, M.A., 2005. The utility of deep-water agglutinated foraminiferal acmes for correlating Eocene to Oligocene abyssal sediments in the North Atlantic and Western Tethys. Studia Geologica Polonica, 124: 325-339.
Kaminski, M.A., Schroder, C.J., 1987. Environmental analysis of deep-sea agglutinated foraminifera: Can we distinguish tranquil from disturbed environments? GCS/SEPM Foundation 8th Annual Research Conference, selected papers and illustrated abstracts: 85-89.

Kaminski, M.A., Gradstein, F.M., Berggren, W.A., 1989. Paleogene benthic foraminifera biostratigraphy and paleoecology at Site 647, Southern Labrador Sea. Proceedings of the Ocean Drilling Program, Scientific Results, 105: 705-730.

Kaminski, M.A., Kuhnt, W., Radley, J., 1996. Paleocene-Eocene deep water agglutinated foraminifera from the Numidian Flysch (Rif, Northern Morocco): their significance for the Paleoceanography of the Gibraltar Seaway. Journal of Micropalaeontology, 15: 1-19.

Kaminski, M.A., Gradstein, F. M., eds. and collaborators, 2005. Atlas of Paleogene cosmopolitan deep-water agglutinated foraminifera. Grzybowski Foundation Special Publication, 10: 1-546.

Keller, G., Herbert, T, Dorsey, R., D'Hondt, S., Johnsson, M., Chi, W.R., 1987. Global distribution of late Paleogene hiatuses. Geology, 15: 199-203

Kelly, D.C., Bralower, T.J., Zachos, J., Premoli Silva, I., Thomas, E., 1996. Rapid diversification of planktonic foraminifera in the tropical Pacific (ODP Site 865) during the late Paleocene thermal maximum. Geology, 24: 423-426.

Kender, S., Kaminski, M.A., Cieszkowski, M., 2005. Foraminifera from the Eocene Variegated Shales near Barwinek (Magura Unit, Outer Carpathians), the type locality of Noth (1912) revisited. Annales Societatis Geologorum Poloniae, 75: 249-271.

Kender, S., Kaminski, M.A., Jones, R.W., 2008. Early to middle Miocene foraminifera from the deep-sea Congo Fan, offshore Angola. Micropaleontology, 54: 477-568.

Kuhnt, W., Kaminski, M.A., 1996. The response of benthic foraminifera to the $\mathrm{K} / \mathrm{T}$ boundary event - a review. Bulletin $\mathrm{du}$ Centres de Recherches Exploration-Production Elf Aquitanie Memoire, 16: 433-442.

Kuhnt, W., Moullade, M., Kaminski, M.A., 1998. Upper Cretaceous, K/T Boundary, and Paleocene agglutinated foraminifers from Hole 959D (ODP Leg 159, Cote D'Ivoire-Ghana transform margin). Proceedings of the Ocean Drilling Program, Scientific Results, 159: 389-411.

Martini, E., 1971. Standard Tertiary and Quaternary calcareous nannoplankton zonation. Edizioni Tecnoscienza, Rome, 2: 739-785.

Melinte, M.C., 2005. Oligocene palaeoenvironmental changes in Romanian Carpathians, revealed by calcareous nannofossils. Studia Geologica Polonica, 124: 341-352.

Miller, K.G., Gradstein, F.M., Berggren, W.A., 1982. Late Cretaceous to early Tertiary agglutinated benthic foraminifera in the Labrador Sea. Micropaleontology, 28: 1-30.

Morgiel, J., Olszewska, B., 1981. Biostratigraphy of the Polish external Carpathians based on agglutinated foraminifera. Micropaleontology, 27: 1-24.

Morgiel, J., Szymakowska, F., 1978. The stratigraphy of the Paleocene and Eocene of Skole Unit. Biuletyn Instytutu Geologicznego, 310: 39-71.

Murray, J., Alve, E., Jones, B., 2011. A new look at modern agglutinated benthic foraminiferal morphogroups: their value in palaeoecological interpretation. Palaeogeography, Palaeoclimatology, Palaeoecology, 309: 229-241.

Mutihac, V., Ionesi, L. 1974. Geologia României. Editura Tehnică, Bucureşti, $648 \mathrm{p}$.

Nagy, J., Gradstein, F.M., Kaminski, M.A., Holbourn, A.E., 1995 Foraminiferal morphogroups, paleoenvironments and new taxa from Jurassic to Cretaceous strata of 41Thakkhola, Nepal. Grzybowski Foundation Special Publication, 3: 181-209.

Oszczypko-Clowes, M., 2001. The nannofossils biostratigraphy of the youngest deposits of the Magura Nappe (East of the Skawa River, Polish Flysch Carpathians) and their palaeoenviromental conditions. Annales Societatis Geologorum Poloniae, 71: $139-188$. 
Oszczypko-Clowes, M., Żydek, B., 2012. Paleoecology of the Upper Eocene-Lower Oligocene Malcov Basin based on calcareous nannofossils: a case study of the Leluchów section (Krynica Zone, Magura Nappe, Polish Outer Carpathians). Geologica Carpathica, 63: 149-164.

Pandele, N., Stănescu, V., 2001. Zăcămintele de Petrol din Flişul Extern Carpatic (in Romanian). Editura Vergiliu, Bucureşti.

Papazzoni, C.A., Sirotti, A., 1995. Nummulite biostratigraphy at the Middle/Upper Eocene boundary in the Northern Mediterranean area. Rivista Italiana di Paleontologia e Stratigrafia, 101: 63-80.

Persico, D., Villa, G., 2004. Eocene-Oligocene calcareous nannofossils from Maud Rise and Kerguelen Plateau (Antarctica): paleoecological and paleoceanographic implications. Marine Micropaleontology, 52: 153-179.

Săndulescu, M., 1984. Geotectonica României. Editura Tehnică, Bucharest.

Săndulescu, M., Micu, M., Bratu, E., 1987. Stratigraphy of the Eocene Flysch formations of the East Carpathians (in Romanian). In: The Eocene from the Transylvanian Basin, Romania (eds. I. Petrescu, L. Ghergari, N. Mészáros and E. Nicorici) 159-164. Geological Formations of Transylvania, Romania 1 Cluj-Napoca, Romania.

Schröder, C.J., 1986. Deep water aracenous foraminifera in the Northwest Atlantic Ocean. Canadian Technical Report of Hydrography and Ocean Sciences, 71: 191.

Serra-Kiel, J., Hottinger, L., Caus, E., Drobne, K., Ferrandez, C., Jauhri, A.K., Less, G., Pavlovec, R., Pignatti, J.S., Samso, J.M., Schaub, H., Sirel, E., Strougo, A., Tambareau, Y., Tosquella, J., Zakrevskaya, E., 1998. Larger foraminiferal biostratigraphy of the Tethyan Paleocene and Eocene. Bulletin de la Societe Geologique de France, 169: 281-299.

Setoyama, E., Kaminski, M.A., Tyszka, J., 2011. The Late Cretaceous-Early Paleocene palaeobathymetric trends in the southwestern Barents Sea - Palaeoenvironmental implications of benthic foraminiferal assemblage analysis. Palaeogeography, Palaeoclimatology, Palaeoecology, 307: 44-58.

Setoyama, E., Radmacher, W., Kaminski, M.A., Tyszka, J., 2013. Foraminiferal and palynological biostratigraphy and biofacies from a Santonian-Campanian submarine fan system in the Vrrring basin (offshore Norway). Marine and Petroleum Geology, 43: $396-408$.

STAS 7107/3-74, 1974. Foundation Ground. Determination of calcium carbonate content. National Comitee for Science and Technology, Romanian Institute of Standardization.

Tremolada, F., Bralower, T.J., 2004. Nannofossil assemblage fluctuations during the Paleocene-Eocene Thermal Maximum at Sites 213 (Indian Ocean) and 401 (North Atlantic Ocean): palaeoceanographic implications. Marine Micropaleontology, 52: 107-116.

Van der Akker, T., Kaminski, M.A., Gradstein, F.M., Wood, J. 2000. Campanian to Palaeocene biostratigraphy and palaeoenvironments in the Foula Basin, west of Shetland Islands. Journal of Micropalaeontology, 19: 23-43.

Varol, O., 1998. Paleogene. In: Calcareous nannofossil biostratigraphy (ed. P.R. Bown): 200-224. British Micropalaeontological Society Series, Chapman and Hall, London.

Verhallen, P.J.J.M., Romein, A.J.T., $1983 . \quad$ Calcareous nannofossils from Priabonian stratotype and correlation with the parastratotype. Utrecht Micropaleontological Bulletin, 29: 163-173.

Villa, G., Persico, D., 2006. Late Oligocene climatic changes: evidence from calcareous nannofossils at Kerguelen Plateau Site 748 (Southern Ocean). Palaeogeography, Palaeoclimatology, Palaeoecology, 231: 110-119.

Villa, G., Fioroni, C., Pea, L., Bohaty, S., Persico, D., 2008. Middle Eocene-Late Oligocene climate variability: calcareous nannofossil response at Kerguelen Plateau, Site 748. Marine Micropaleontology, 69: 173-192.

Wei, W., Wise, S.W., 1990. Biogeographic gradients of middle Eocene-Oligocene calcareous nannoplankton in the South Atlantic Ocean. Palaeogeography, Palaeoclimatology, Palaeoecology, 79: 29-61.

Wei, W., Villa, G., Wise Jr., S.W., 1992. Paleoceanographic implications of Eocene-Oligocene calcareous nannofossils from Sites 711 and 748 in the Indian Ocean. Proceedings of the Ocean Drilling Program, Scientific Results, 120: 979-999. 